Krasinsky Vladislav, Doctor of law, an expert of the Russian public institute of electoral law (ROIIP)

Dedicated to the Head of Department of the regional legislation the CEC of Russia Natalia Kiseleva, tragically died from terrorism in the Moscow metro February 6, 2004

Source of publication: Krasinsky $V . V$. Involvement of organized criminal groups in election campaigns // Politics and Society. Number 4. 2008. P. 7-13; www.krasinskiy.ru

\title{
Involvement of organized criminal groups in election campaigns
}

Development of economic relations in the Russian Federation, held in the period of significant weakening of the regulatory role of the state in the economy, the absence of the necessary regulatory framework of the market economy, largescale division of state property by using illegal methods and means led to a massive involvement in economic processes representatives of organized criminal groups and the gradual establishment of a criminal warning light on a significant number of business entities ${ }^{1}$.

The interest of criminal groups in a constant build-up of their income is a direct correlation of formal and informal economic activities on the political situation in the Russian Federation, a desire to ensure the personal security of leaders led to the desire of criminals to legalize their status, and actively participate in the political decision-making.

Convenient channel for the implementation of this criminal interest was the participation of organized criminal groups in election campaigns held in the Russian Federation.

As the purpose of the involvement of organized criminal groups in election campaigns should be called the conquest of state power associated with the subsequent reorientation of public and municipal elected institutions for the continuous maintenance of criminal interests.

Achieving this goal is connected with the need to solve a number of promising tasks by criminal groups.

The prospective tasks of participation of organized criminal groups in electoral campaigns can be classified into two main groups: political and economic.

\footnotetext{
${ }^{1}$ Here and below, an organized criminal group means a stable and cohesive criminal organization that has a hierarchical structure and is created to commit serious or particularly serious crimes. Organizers, leaders, participants and other representatives of an organized criminal group are defined as criminals.
} 
Among the political tasks of organized criminal groups related to the election of representatives of criminals in the bodies of state power and local selfgovernment ${ }^{2}$ :

- substitution of elective posts of municipal entities with a view to the subsequent use of official powers in the interests of organized criminal groups;

- the formation in the federal and regional government bodies of the deputy corps, lobbying the adoption of regulatory legal acts, political, administrative and other formal decisions in the interests of organized criminal groups;

- acquisition of immunities of elected officials and deputy immunity.

The prospective economic tasks of organized criminal groups associated with the election of their representatives to the bodies of state power and local selfgovernment include:

- legal redistribution of markets for raw materials, real estate, goods and services for the benefit of organized criminal groups;

- establishment of control over profitable budget-forming enterprises and highly profitable sectors of the economy (construction, fuel and energy complex, extractive industry, credit and financial institutions);

- illegal receipt of additional benefits and preferences (export-import transactions, taxes, licensing, quotas)

- unlawful receipt of loans and management of budgetary funds in the interests of organized criminal groups.

The complex of tasks of participating in election campaigns facing organized criminal groups determine the choice by representatives of criminals of appropriate methods of struggle for state power in the conditions of elections. During the preparation and conduct of elections, representatives of organized criminal groups use, along with legal methods of political struggle, the following methods:

- bribery of the leadership of political parties, regional branches of political parties, members of election commissions, judges, law enforcement officials, journalists. (Practice shows that $2 / 3$ of the total amount of criminal proceeds is spent on bribing officials - objects of interest of organized criminal groups.) The introduction of a proportional system for the election of deputies to the State Duma of the Federal Assembly of the Russian Federation and the legislative bodies of state power of the subjects of the Russian Federation did not fundamentally change the situation If previously representatives of organized criminal groups were elected from the territories under their control - the relevant single-mandate or multi-member districts, or bought "passing" seats in party lists, now the role of party corruption in the political process has increased substantially).

\footnotetext{
${ }^{2}$ The bodies of state power and local self-government in the Russian Federation, formed through elections, are the President of the Russian Federation, the State Duma of the Federal Assembly of the Russian Federation, the legislative authorities of the Russian Federation, representative bodies of the municipalities, elected officials of municipalities. It should be noted that no evidence has been received to date of the aspirations of representatives of criminals to be elected to the post of President of the Russian Federation. With this in mind, the author does not consider the participation of criminal groups in the election of the President of the Russian Federation.
} 
- bribery of voters;

- blackmail of party functionaries, members of election commissions, journalists, judges;

- compromising honest and competent officials and law enforcement officials;

- compulsory delivery of voters by the transport of a candidate for polling stations;

- destruction of property (arson of premises, transport, public reception rooms and election headquarters of candidates);

- violent actions against political competitors, members of their families and relatives (including committing murders). ${ }^{3}$

The implementation of the tasks of participation of organized criminal groups in election campaigns depends not only on the methods used by representatives of criminals for the struggle for state power in the conditions of elections, but also on the influence of a number of key factors.

It is necessary to distinguish the factors contributing to the implementation of the tasks of participation of organized criminal groups in election campaigns, as well as the factors that complicate the tasks of participation of organized criminal groups in election campaigns.

Among the most significant factors contributing to the implementation of the tasks of participation of organized criminal groups in election campaigns, one can single out political-legal, material-technical, organizational and ideological factors.

The politico-legal factor includes miscalculations of the country's leadership and senior officials of the subjects of the Russian Federation in conjunction with their unwillingness (fear) to counteract the criminalization of state authorities and local self-government. In practice, representatives of criminals have long been implementing certain state powers and functions of state and municipal bodies ${ }^{4}$. Candidates of organized criminal groups express the interests of a number of social groups in Russian society and have support in society ${ }^{5}$. According to the Public Opinion Survey of the All-Russian Interrogation of the Urban and Rural Population of 44 Subjects of the Russian Federation, $4 \%$ of the respondents believe that only members of organized criminal groups can bring order to the state, because "crime has become accustomed to discipline," " their environment ". $2 \%$

\footnotetext{
${ }^{3}$ For example, the murder in 2006 of a candidate for the post of the Head of the Administration of Dalnegorsk, Primorsky Krai, D. Fotyanov. See: the Statement of the Presidium of the General Council of "United Russia" of 20.10.2006 "Let's not allow crime to power".

${ }^{4}$ For example, "shadow justice".

5 The social base of stable support for representatives of criminals in the elections is mainly those who are under investigation in places of detention (pre-trial detention facilities, IVS), previously and repeatedly convicted, their connections, youth. The criminal potential of the population, ready to justify and support criminal activity, is considerable. According to experts, in Russia, a "school" of correctional institutions passed 15-18 million people; the number of persons who commit latent crimes is approaching 15 million; the number of crimes committed annually is about 3 million; approximately 5 million crimes are officially considered not to be disclosed. Consequently, 35-40 million people (almost every third adult Russian) are involved in criminal activities. See: Criminology: uch. for universities / ed. V.D. Malkov. Moscow: ZAO Justicinform, 2006. P. 421.
} 
of respondents consider the representatives of the criminal environment to be honest, fair, intelligent people with a lot of life experience, able to keep the word ("they understand life better", "they are often more decent than politicians") ${ }^{6}$.

Another component of the political and legal factor is the lack of effective regulatory and legal restrictions on the election of representatives of organized criminal groups in government and local government. Persons who are wanted or under investigation may be registered as candidates and - then - elected. It is important to emphasize that according to the current election legislation, the availability of operationally relevant information on the links of candidates with representatives of organized criminal groups is not grounds for refusing to register a candidate (list of candidates), expelling a candidate from the list, canceling the registration of a candidate (list of candidates) or canceling registration candidate (list of candidates) ${ }^{7}$.

The material and technical factor plays an important role in the implementation of the tasks of participation of organized criminal groups in election campaigns. Deficits of local and regional budgets, on the one hand, and the availability of significant material resources at the disposal of organized criminal groups, on the other hand, contributed to the formation of the interest of authorities in cooperation with organized criminal groups, and in the future, the dependence of state and municipal bodies on representatives of criminals. The economic strength of organized criminal groups and financial and industrial structures controlled by them allows representatives of criminals to be the main sponsors of election campaigns, to monitor the activities of judges, election commissions, law enforcement agencies and the media. In the period of preparation and conduct of elections, candidates representing criminal groups often demonstrate readiness and ability to solve socially important issues: pave roads, install memorial plaques to war veterans participating in the Great Patriotic War, build playgrounds and seek to participate in the implementation of economic programs and priority national projects.

The organizational factor that contributes to the implementation of the tasks of participation of criminal groups in election campaigns is manifested in the fact that teams of candidates of organized criminal groups tend to have better funding, a broader opportunity for recruitment of professional election organizers, and a built-up management system in which the formulation of clear and real tasks, the minimization of bureaucratic red tape, the distribution of roles, strict subordination, control and mutual responsibility are combined performers ${ }^{8}$.

\footnotetext{
${ }^{6}$ See: A. Petrova Crime in power - a common phenomenon? //bd.fom.ru/report/map/projects. See also. Work. 2004. 10th of August. No. 148.

${ }^{7}$ See: P. 24 of Art. 38, art. 76 of the Federal Law "On Basic Guarantees of Electoral Rights and the Right to Participate in a Referendum of Citizens of the Russian Federation", Art. 44 and 91 of the Federal Law "On Elections of Deputies of the State Duma of the Federal Assembly of the Russian Federation", Art. 39 and 84 of the Federal Law "On Elections of the President of the Russian Federation".

${ }^{8}$ According to a survey of citizens of Omsk, held in April 2002, 25, 3\% of respondents among the attractive features of representatives of criminals named efficiency and ability to solve problems. See: Sanin V.A. Bandits and us / Crime in Russia and the fight against it: a regional aspect. M., Russian Criminological Association, 2003. P. 83.
} 
The ideological factor is gaining more and more importance in the success of representatives of criminals in elections. As shown by the electoral practice, in the public consciousness of the population of a number of constituent entities of the Russian Federation, tolerance and sympathy among the population against elected representatives of organized criminal groups and criminal candidates for elected positions in bodies of state power and local self-government have been formed. In a number of subjects of the Russian Federation, representatives of criminals are respected among the population ${ }^{9}$. The features of the criminal subculture (the cult of violence and parasitism, antisocial norms - customs, gambling, jargon, swearing, nicknames, tattoos, thieves' songs) penetrated into everyday life and are regularly reproduced in separate social groups of Russian society ${ }^{10}$. It should be noted that representatives of organized criminal groups actively support the strengthening of criminal influence in society, including among youth. There are cases of organization of sports sections, clubs on interests, entertainment centers and discos, which are influenced by representatives of organized crime and funded from their sources. The mentality of the "brothers" has spread even in the federal bodies of state power and administration.

It should also highlight the factors that make it difficult to implement the tasks of participation of organized criminal groups in election campaigns. These include:

conformity of the policy conducted by state authorities and local selfgovernment to the interests of combating organized crime;

support by the population of measures taken by the leadership and officials of state authorities and local self-government to combat organized crime;

close coordination of the activities of law enforcement agencies, the media and public organizations in order to prevent representatives of criminals from entering government and local government bodies;

improvement of legislation on elections by establishing legal restrictions on the election of persons under investigation in the search for bodies of state power and local self-government, who have a criminal record for committing grave or especially serious crimes, etc.;

restriction of the number and content of immunities of elected officials and deputy immunity.

The process of entering of criminals into the bodies of state power and local self-government of the Russian Federation consisted of two main stages.

\footnotetext{
${ }^{9}$ Often the representatives of state power themselves strengthen the faith of the population in the omnipotence of bandits. How can you relate to state and municipal bodies, whose leadership willingly accepts the funds listed by criminal authorities in the order of charity? How can you respect the state power, which can not protect itself (not citizens!) From representatives of criminals? Dependence of state power on criminal groups entails an increase in criminal influence in all spheres of public life.

${ }^{10}$ See: Malikov B.Z. Strengthening of crime in the sphere of spirituality of society and some problems of strengthening law and order / Problems of legal culture. M, Criminological Association, 2002. P. 7. See also Anisimkov, V.M. Criminal subculture and its neutralization in the Institute of Management of Russia. Author's abstract. dis. Dr. jurid. sciences. Moscow: Academy of Management of the Ministry of Internal Affairs of the Russian Federation, 1998. P.3.
} 
At the stage of the primary politicization of organized crime (1995-1999), the most active promotion by organized criminal groups of their candidates to the bodies of state power and local self-government took place ${ }^{11}$. This circumstance in largely due to the fact that until 1999, the legislation on elections lacked provisions related to the need for candidates to inform election commissions about their criminal liability. In connection with the entry into force of the Federal Law of March 30, 1999 No. 55-FZ "On Amendments and Additions to the Federal Law" On Basic Guarantees of Electoral Ethics and the Right to Participate in the Referendum of Citizens of the Russian Federation ", the duty to indicate candidates for elected posts of information on unacknowledged or outstanding convictions with the clarification of the number(s) and title of the article of the Criminal Code of the Russian Federation on the basis of which the candidate was convicted, as well as article (articles) of the criminal code adopted in the law in accordance with the Fundamentals of the Criminal Legislation of the USSR and the Union Republics, article (articles) of the law of a foreign state if the candidate was convicted in accordance with the above-mentioned legislative acts for acts recognized by the current Criminal Code of the Russian Federation as a crime.

Acceleration of the primary politicization of organized crime was closely related to the earlier change in the structure of the criminal community. Along with the "thieves in the law" criminal leaders of the "scumbags" began to play an active role in the criminal environment, ignoring and flagrantly violating the thieves' traditions (national hostility, refusal to prohibit participation in political and public life, committing murders, assaults on "lawyers"12. This part of the representatives of the criminal environment in the 90's showed the greatest activity connected with the election to the bodies of state power and local self-government.

After achieving this goal, the representatives of criminal law legalized their status in state and local government bodies, obtained legal access to financial resources and began to make wide use of the state apparatus for carrying out and reproducing criminal activities. At this stage of penetration of criminals into the authorities, there was a final merger of organized criminal groups with elements of the state mechanism and local self-government in a number of subjects of the Russian Federation.

The transition to a proportional system of elections to the State Duma of the Federal Assembly of the Russian Federation, the establishment of legal restrictions

\footnotetext{
${ }^{11}$ It should be emphasized that the entry of criminal records into organs state power and local self-government was carried out and implemented far not only in the conditions of elections. Involvement of deputies, elected officials, specific federal, regional and municipal employees (in some cases - their entourage) to long-term charged confidential cooperation (corrupting the state mechanism and local self-government) is a priority task of intelligence and counterintelligence of any organized criminal group. However, it should be borne in mind that not every bribe-taker is of interest to organized criminal groups and is naturally associated with organized criminal activity.

12 "Thief in the Law" - is a recognized leader of the underworld, who, as a rule, great criminal experience and consistently adhering to the norms of the thieves' community. For a more detailed description of leaders and participants in organized criminal groups, see: V.G. Grib. Counteraction to organized crime. M .: Infra-M, 2001. P. 43-46; Criminology: uch. for universities / ed. V.D. Malkov. Moscow: ZAO Justicinform, 2006. P. 395-396.
} 
on the election to bodies of state power and local self-government of persons who have an unexpunged and unpaid conviction for committing grave and (or) particularly serious crimes, extremist crimes, details of financing the participation of political parties in elections, toughening of legal responsibility for violation of the procedure for financing the election the withdrawal of licenses from a number of institutions of the credit and banking system suspected of involvement in money laundering, the high efficiency of using the powers of corrupt leaders and officials of the federal and regional systems of the state apparatus in the interests of organized criminal groups, which does not require personal representation of criminals in the bodies government and local self-government, entailed a change in the tactics of criminals to promote their own candidates to the governmental bodies $^{13}$.

The statistics of regional and municipal elections held in 2006-2008 testifies to new tendencies of participation of organized criminal groups in election campaigns.

First, at the present time the number of representatives of organized criminal groups, directly running for deputies or for elected offices, has significantly decreased. Now the leaders of the criminal environment offer promising candidates their participation in the financing of the election campaign, or independently prepare in advance for the implementation of their "unseasoned" henchmen who do not have convictions that have not compromised themselves with identified links with organized criminal groups to the bodies of state power and local self-government.

Secondly, despite the legalization of status and income, none of the deputies or elected officials who are leaders of the criminal environment has disbanded their militant groups ("militants"). As a rule, these structures operate under the cover of private security companies or security services. ${ }^{14}$ Thus, during the organization and conduct of elections among representatives of organized criminal groups, it is possible to use the power influence on the electoral process to influence the adoption of political decisions, destabilization of the situation and deterrence of the population. In addition, the leaders of ethnic criminal groups operating in the territory of the Russian Federation can use their combat units during interethnic clashes that periodically arise in certain constituent entities of the Russian Federation.

Thirdly, taking into account the increasing role of political parties in the electoral process, the most important task of criminal intelligence and

\footnotetext{
${ }^{13}$ See Federal Law No. 51-FZ of May 18, 2005 "On Elections of Deputies to the State Duma of the Federal Assembly of the Russian Federation"; Federal Law No. 93-FZ of July 21, 2005 "On Amendments to the Legislative Acts of the Russian Federation on Elections and Referenda and Other Legislative Acts of the Russian Federation"; Federal Law No. 225-FZ of 05.12.2006 "On Amendments to the Federal Law" On Basic Guarantees of Electoral Rights and the Right to Participate in a Referendum of Citizens of the Russian Federation "and the Civil Procedure Code of the Russian Federation", etc.

${ }^{14}$ In a number of cases, "militants" are registered in the staff of legal entities controlled criminal groups.
} 
counterintelligence was the establishment of control over organized political groups over existing political parties (regional branches of political parties) and promotion of their representatives to government bodies and local self-government using party structures.

Fourth, representatives of organized criminal groups practically stopped money laundering during the elections. This circumstance is due to the presence of organized criminal groups of diverse legal sources of financing election campaigns and toughening legal responsibility for violating the procedure for financing elections.

These trends in the participation of organized criminal groups in election campaigns make it difficult for the law enforcement bodies to focus their activities on preventing criminals from entering the government and local government during the elections and increasing the public danger of such processes.

The public danger of electing representatives of organized criminal groups to the bodies of state power and local self-government is manifested from different sides $^{15}$.

The replacement of elective posts by representatives of organized criminal groups inevitably leads to an increase in the shadow economic potential, which is under the control of criminals. Criminal groups gain access to the management of budget funds, the allocation of resources and benefits, which allows them to occupy a leading position in the economy of the subjects of the Russian Federation.

Adoption of legal acts lobbied by organized criminal groups discredits representative bodies of state power (local self-government) and legislative acts passed by deputies. The implementation of criminal activities and lawmaking exclude the combination due to their incommensurability. The legal regulation of public relations in the interests of criminal groups entails an irreversible deformation of the legal conscience of broad sections of the population and strengthens legal nihilism.

Acquisition of power by representatives of criminals, immunities of elected officials and deputy immunity is detrimental to the state of law and the fight against organized crime. Representatives of the criminal environment elected to state authorities and local self-government effectively use the power to fight their competitors, for undue influence on law enforcement officers, prosecutors and judges. The difficulty of bringing to account the representatives of criminal criminals with immunities, the support of criminal groups by corrupt leaders and state employees, including law enforcement agencies, facilitate the dismissal of honest employees and qualified specialists from the state apparatus ${ }^{16}$.

\footnotetext{
15 The following manifestations of public harm, as a rule, apply to the provision of various services to representatives of criminals by electoral candidates and political parties financed by organized criminal groups.

${ }^{16}$ Deeply erroneous and dangerous is the point of view about the futility of fighting already legalized representatives of criminals. Such a conniving position often justifies inaction of the highest officials of the subjects of the Russian Federation and the leadership of law enforcement agencies and leads to the formation in the Russian Federation of
} 
Bearing this in mind, immediate and systematic implementation of the complex of nation-wide (political, legal, organizational, personnel, information and propaganda) and special measures to counteract the public and state bodies to advance their candidates to state and local government bodies in the conditions of elections is organized by organized criminal groups.

State measures to counteract the public and state bodies to promote their candidates to government bodies and local self-government by organized criminal groups in the conditions of elections should be aimed at compulsory elimination of the causes of criminalization of bodies of state power and local self-government. The participation of the public and the media in the fight against the criminalization of the authorities is necessary, since often the legalized representatives of criminals not only do not oppose the advancement by organized criminal groups of their candidates to state and local government bodies under election conditions, but also actively support such attempts, using their own state -powerful authority ("administrative resource").

Among the state-wide political measures to counteract the public and state bodies, the advancement of their candidates to state and local government bodies by organized criminal groups includes official instructions of the head of state, senior officials of the subjects of the Russian Federation to the heads of election commissions and law enforcement agencies to prevent participation in political life and election of representatives of criminals, the development of federal and regional programs to combat the criminalization of state authorities and local selfgovernment; "Anti-criminal pacts" of political parties before federal and regional elections ${ }^{17}$. The neutralization of organized crime requires, first of all, the political will of the highest officials of the state and regions, as well as concerted, consistent activities of the public, the media and state bodies.

Legal measures to combat the criminalization of public authorities and local self-government provide for the improvement of legislation by establishing legal restrictions on the election to bodies of state power and local self-government of persons on federal wanted list who have a criminal record (including those that have been withdrawn and extinguished) for committing serious or particularly serious crimes. In federal election laws, it is proposed to fix the mandatory submission of all available convictions (including those that have been withdrawn and canceled) to candidates and (or) elected offices, as well as informing political parties and electoral commissions of voters about all convictions of candidates. In order to suppress unlawful activities and prepare materials for bringing to account

criminal-state regions officially administered by organized criminal groups. It seems that the political and legal mistakes made in the state practice must be corrected, and not tolerated with them. Whichever positions gangsters occupy today, the title of the post, the scope of useful communications and the number of state awards can not serve as an excuse for committed crimes. Legal responsibility must be inevitable for all.

${ }^{17}$ As an example of such an "anti-criminal pact" can be cited "Agreement on countering the penetration of crime into power", signed on July 10, 2006 in Yekaterinburg by representatives of United Russia, the LDPR, the Communist Party, The Russian Party of Pensioners, the Russian Communist Workers' Party, the Yabloko Party, the Patriots of Russia, the Democratic Party of Russia, and the Motherland. 
the representatives of criminals elected to the bodies of state power and local selfgovernment, it is proposed to use the institution of suspension of powers of deputies and elected officials. With this in mind, the Federal Law "On the status of a member of the Federation Council and the status of a deputy of the State Duma of the Federal Assembly of the Russian Federation" seems to be appropriate to supplement the Federal Law (as amended on 05.07.1999 No. 133-FZ, as amended on 02.03.2007) 41: "Suspension of the powers of a member of the Federation Council, a deputy of the State Duma of the Federal Assembly of the Russian Federation" as follows:

"1. The powers of a member of the Federation Council, a deputy of the State Duma of the Federal Assembly of the Russian Federation shall be suspended in the following cases:

a) the initiation of a criminal case against a member of the Federation Council, a deputy of the State Duma of the Federal Assembly of the Russian Federation under articles of the Criminal Code of the Russian Federation, providing for punishment for committing grave and (or) especially serious crimes;

b) the institution of a criminal case against a member of the Federation Council, a deputy of the State Duma of the Federal Assembly of the Russian Federation under the articles of the Criminal Code of the Russian Federation, which provides for punishment for committing extremist crimes;

c) the announcement of a member of the Federation Council, a deputy of the State Duma of the Federal Assembly of the Russian Federation in the federal wanted list.

2. The decision to suspend the powers of a member of the Federation Council, a deputy of the State Duma of the Federal Assembly of the Russian Federation shall be formalized by an appropriate resolution of the Federation Council, the State Duma of the Federal Assembly of the Russian Federation, which determines the date of suspension of the powers of a member of the Federation Council, a member of the State Duma of the Federal Assembly of the Russian Federation."

Similar norms could be reproduced in the legislation of the constituent entities of the Russian Federation, which determines the status of deputies and elected officials.

The organizational and personnel measures to counteract criminals should cover two groups of measures. The first group of measures to counteract the internal party policy: checking candidates for party membership, identifying the facts of party corruption and transferring the collected materials to law enforcement agencies, checking party members running for party lists, expelling from the party those who compromised themselves with links to extremist organizations and organized criminal groups. The second group of measures is related to the improvement of the staffing of the whole system of state bodies. It should be noted that until recently, the personnel policy in the government and 
management bodies was mainly focused on attracting a little-tested contingent lacking sufficient professional training and education ${ }^{18}$. In the process of counteraction of the public and state bodies to the promotion of their candidates to government bodies and local self-government in the conditions of elections by organized criminal groups, it is necessary to predict the pressure on the part of legalized representatives of criminals (corrupt officials representing criminal interests) on specific leaders and officials, carrying out the fight against organized crime, and in advance to work out measures to neutralize such pressure and ensure the safety of involved civil servants, law enforcement officers, party functionaries, journalists. In the cooperation of law enforcement agencies, justice, the federal security service, the prosecutor's office in the fight against the criminalization of government bodies with the apparatus of plenipotentiary representatives of the President of the Russian Federation in federal districts, it is impossible to exclude possible leaks of operationally meaningful information to representatives of criminals. In this regard, measures should be envisaged to localize the negative consequences of such leaks.

Measures of the information and propaganda opposition of the public and state bodies to the promotion of their candidates to the bodies of state power and local self-government by organized criminal groups in the conditions of elections should be aimed at raising the legal culture of the society. It is expedient to give special attention to the preventive work of election commissions, law enforcement bodies, state authorities of the subjects of the Federation in the youth environment. Extremely important is the work of the media on the consolidation of Russian society and the formation of negative public opinion in relation to the activities of criminal groups, criminal leaders, facts and plans for their participation in political life and attempts to be elected to government bodies and local self-government.

The effectiveness of the system of nationwide measures is supplemented by special measures to counteract law enforcement agencies by promoting organized criminal groups of their candidates to government bodies and local selfgovernment under election conditions. Special measures include the acquisition of sources from among organized middle and senior-level criminal groups in order to obtain information about plans, personnel of criminal groups, officials of state and municipal bodies that assist criminal groups in illegal activities, sources and channels of illegal financing of elections and political activities aimed at damaging the security of the Russian Federation. It is important to work in a "near criminal" environment to obtain information about the connections of candidates representing the interests of organized criminal groups, with the functionaries of political parties, members of election commissions, law enforcement officials, corruption in political parties, public organizations, state and municipal bodies.

An integral part of special measures is the consistent documentation of

\footnotetext{
${ }^{18}$ See: Yutskova E.M. Citizens and Power: Some Criminological Aspects / Criminality and Power. Conference proceedings. Moscow: Russian Criminological Association, 2000. P. 31.
} 
organized criminal activity with a view to preparing materials to attract leaders and participants of criminal groups to criminal liability. It should be noted that under present conditions, documentation of organized criminal activity is not fully implemented ${ }^{19}$. At present, more than $60 \%$ of law enforcement officers are sure that only some episodes of criminal activity of certain members of criminal groups are reflected in criminal cases, and the activities of criminal groups themselves are not considered at all ${ }^{20}$. A prerequisite for the operational documentation of unlawful activities is to ensure the safety of law enforcement officers and operational sources involved. As a final result, it is necessary to consider the liquidation of organized criminal groups (retention in red, arrest and prosecution of organizers and participants of criminal groups).

A separate area of work is the documentation of the activities of organized criminal groups that have international connections. In order to improve the quality of documentation and prepare adequate measures to counteract criminals, it is important to develop an information exchange with Interpol, the Bureau for Coordination of Combating Organized Crime of the CIS countries, foreign special services and law enforcement agencies.

Participation of organized criminal groups in electoral campaigns must give way to civilized legal forms of political activity in the Russian Federation.

\footnotetext{
${ }^{19}$ In this connection, in the structure of the General Prosecutor's Office or the Security Council of the Russian Federation, it seems advisable to create a single Analytical Center in which information about the illegal activities of Russian organized criminal groups in all constituent entities of the Federation and abroad, information on the penetration of representatives of criminals into the state bodies would be accumulated and systematized authorities and local self-government, elected leaders and bodies of state power and local self-government organized criminal groups, on the progress of the preliminary investigation and the judicial examination of criminal cases on the types of crimes provided for by Art. 208-210 of the Criminal Code of the Russian Federation. The Head of the Center is supposed to be given the responsibility of regularly informing the President and heads of higher state bodies about the real criminal situation in the Russian Federation, threats to the security of the Russian Federation by organized criminal groups and measures taken to combat organized crime.

${ }^{20}$ See: Yutskova E.M. Crime in the sphere of functioning of criminal environment and its changes / Crime in Russia and the fight against it: a regional aspect. M., Russian Criminological Association, 2003. P. 21.
} 